\title{
Extraosseous Ewing's sarcoma, a case report on a rare diagnosis in an 80-year-old woman with a large abdominal mass
}

\begin{tabular}{|c|c|}
\hline \multicolumn{2}{|c|}{$\begin{array}{l}\text { Authors: } \\
\text { Charlotte de Wilde }^{1} \text { (D) } \\
\text { Alain Bols }^{2} \\
\text { Ivo van den Berghe } \\
\text { Kenneth Coenegrachts }\end{array}$} \\
\hline $\begin{array}{l}\text { Affiliations: } \\
{ }^{1} \text { Department } \\
\text { Ghent Univers }\end{array}$ & $\begin{array}{l}\text { ff Radiology, } \\
\text { ity, Belgium }\end{array}$ \\
\hline $\begin{array}{l}{ }^{2} \text { Department } \\
\text { St.-Jan Brugge } \\
\text { Belgium }\end{array}$ & $\begin{array}{l}\text { f Oncology, AZ } \\
\text {-Oostende, }\end{array}$ \\
\hline $\begin{array}{l}{ }^{3} \text { Department } \\
\text { St.-Jan Brugge } \\
\text { Belgium }\end{array}$ & $\begin{array}{l}\text { f Pathology, AZ } \\
\text {-Oostende, }\end{array}$ \\
\hline $\begin{array}{l}{ }^{4} \text { Department } \\
\text { St.-Jan Brugge } \\
\text { Belgium }\end{array}$ & $\begin{array}{l}\text { ff Radiology, AZ } \\
\text {-Oostende, }\end{array}$ \\
\hline $\begin{array}{l}\text { Correspondin } \\
\text { Charlotte de V } \\
\text { charlotte.dew } \\
\text { com }\end{array}$ & $\begin{array}{l}\text { g author: } \\
\text { Vilde, } \\
\text { ilde@hotmail. }\end{array}$ \\
\hline $\begin{array}{l}\text { Dates: } \\
\text { Received: } 26 \mathrm{~J} \\
\text { Accepted: } 14 \text { I } \\
\text { Published: } 29\end{array}$ & $\begin{array}{l}\text { an. } 2017 \\
\text { Mar. } 2017 \\
\text { May } 2017\end{array}$ \\
\hline $\begin{array}{l}\text { How to cite th } \\
\text { De Wilde C. Bc } \\
\text { Berghe I. Coen } \\
\text { Extraosseous } \\
\text { sarcoma, a cas } \\
\text { rare diagnosis } \\
\text { 80-year-old wc } \\
\text { large abdomin } \\
\text { Rad. 2017; } 21 \\
\text { https://doi.org } \\
\text { v21i1.1183 }\end{array}$ & $\begin{array}{l}\text { is article: } \\
\text { ls A. Van den } \\
\text { legrachts K. } \\
\text { Ewing's } \\
\text { e report on a } \\
\text { in an } \\
\text { oman with a } \\
\text { al mass. S Afr J } \\
\text { (1), a1183. } \\
\text { /10.4102/sajr. }\end{array}$ \\
\hline $\begin{array}{l}\text { Copyright: } \\
\text { (C) 2017. The A } \\
\text { Licensee: AOS } \\
\text { is licensed unc } \\
\text { Creative Comn } \\
\text { Attribution Lic }\end{array}$ & $\begin{array}{l}\text { uthors. } \\
\text { IS. This work } \\
\text { ler the } \\
\text { nons } \\
\text { ense. }\end{array}$ \\
\hline Read online: & \\
\hline 口9rip & $\begin{array}{l}\text { Scan this QR } \\
\text { code with your } \\
\text { smart phone or } \\
\text { mobile device } \\
\text { to read online. }\end{array}$ \\
\hline
\end{tabular}

Extraosseous or extraskeletal Ewing's sarcoma is a very rare mesenchymal soft tissue malignancy. We report on a case of abdominal swelling in an 80-year-old woman caused by a large intra-abdominal EES. This case report illustrates that Ewing's sarcoma can occur in adults and elderly, and highlights the importance of early diagnosis because of poor prognosis.

\section{Introduction}

This case report demonstrates the rare diagnosis of an extraskeletal Ewing sarcoma (EES) in an elderly woman with a large abdominal mass. EES is commonly diagnosed in a younger population, which makes our case very unusual. This article discusses the presentation and typical radiological appearance of extraskeletal Ewing sarcoma and the differential diagnoses with their radiological appearances.

\section{Case report}

An 80-year-old female patient was referred by her general practitioner and presented at the radiology department for an abdominal ultrasound. She complained about painless abdominal swelling for several weeks. A firm intra-abdominal mass was palpable during clinical examination. The abdominal ultrasound showed a large, heterogeneous and minimally vascularised intra-abdominal midline mass, measuring about $25 \mathrm{~cm} \times 20 \mathrm{~cm}$ (Figure 1).

The ultrasound was followed by a computed tomography (CT) scan of the abdomen with oral and intravenous contrast agent. CT showed a large $(20 \mathrm{~cm} \times 27 \mathrm{~cm} \times 16 \mathrm{~cm})$ (Figure 2), lobulated mass with heterogeneous contrast uptake, lack of calcifications and central necrosis, probably originating from the mesentery. There was no evidence of invasion of the adjacent small bowel. No metastatic lesions were seen. An ultrasound-guided core biopsy was performed (Figure 3).

Microscopic examination of the biopsy sample revealed a high-grade small blue round cell tumour, immunohistochemically compatible with an extraskeletal Ewing's sarcoma (Figure 4). The diagnosis was confirmed with fluorescence in situ hybridisation (FISH) cytogenetic evaluation and immunohistochemistry staining, the latter showing positive CD 99 and synaptofysine staining (Figure 5).

\section{Discussion}

Ewing's sarcoma is a high-grade rounded cell sarcoma, which arises from both skeletal and extraskeletal mesenchymal cells with a $\mathrm{t}(11 ; 22)$ chromosomal translocation. However, there are important differences between the extraosseous and the osseous type of Ewing's sarcoma. These differences mainly comprise age distribution, clinical presentation, prognosis, treatment and survival. EES is more common in adults, although usually in young adults in contrast to our case. Adults tend to have a worse prognosis than children with this presentation of Ewing's sarcoma. A possible explanation for the worse outcome in adults is the inability to tolerate the aggressive chemotherapy. ${ }^{1,2}$

It is important to recognise that approximately $20 \%$ of all cases of Ewing's sarcomas occur in patients older than 18 years and at least $50 \%$ of these patients have an extraskeletal presentation. The most prevalent extraskeletal sites are the chest (most common), the abdomen (both intra- and retroperitoneal), the soft tissues of the extremities (the gluteal region and the lower extremities are 


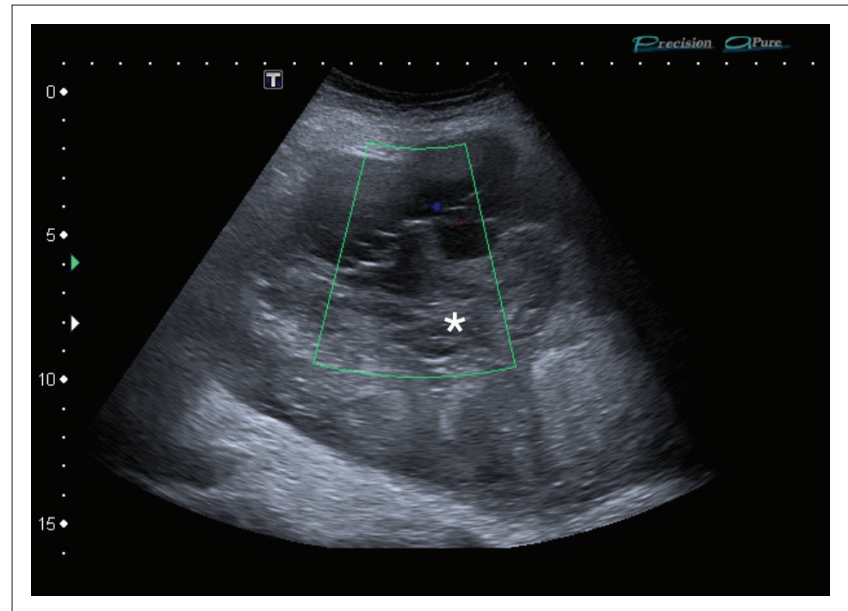

FIGURE 1: Ultrasound image of the mass with Doppler technique, showing a large, heterogeneous and minimally vascularised intra-abdomina mass, situated on the midline and measuring about $25 \mathrm{~cm} \times 20 \mathrm{~cm}$ (asterisk).

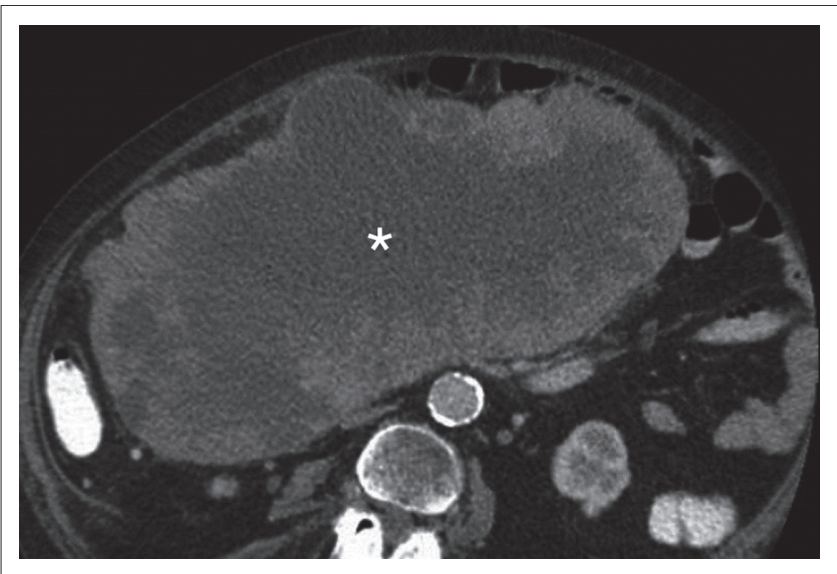

FIGURE 2: Axial computed tomography images of the mass, showing a large $(20 \mathrm{~cm} \times 27 \mathrm{~cm} \times 16 \mathrm{~cm})$, lobulated mass with heterogeneous contrast uptake, lack of calcifications and central necrosis, originating from the mesentery (asterisk). Evident mass effect but no invasion of the adjacent small bowel.

relatively common sites) and the head and neck region (most rare location). ${ }^{2,3,4}$

On CT, abdominal EESs show heterogeneous contrast enhancement with hypoattenuating areas corresponding to necrosis and high-density foci in cases of haemorrhage. Calcification is atypical, occurring in approximately $10 \%$ of tumours at presentation. When present, it appears faint and amorphous. ${ }^{2,4}$ Most abdominal EESs are unilateral and do not cross the midline, in contrast to our case. ${ }^{3}$

The radiological differential diagnosis for abdominal EES includes:

- other peritoneal tumours such as lymphoma, peritoneal metastasis and lymph node metastases (often with associated retroperitoneal lymph node enlargement)

- gastrointestinal stromal tumours (GIST) (gastric or small bowel GIST, extends exophytically from the gastrointestinal tract)

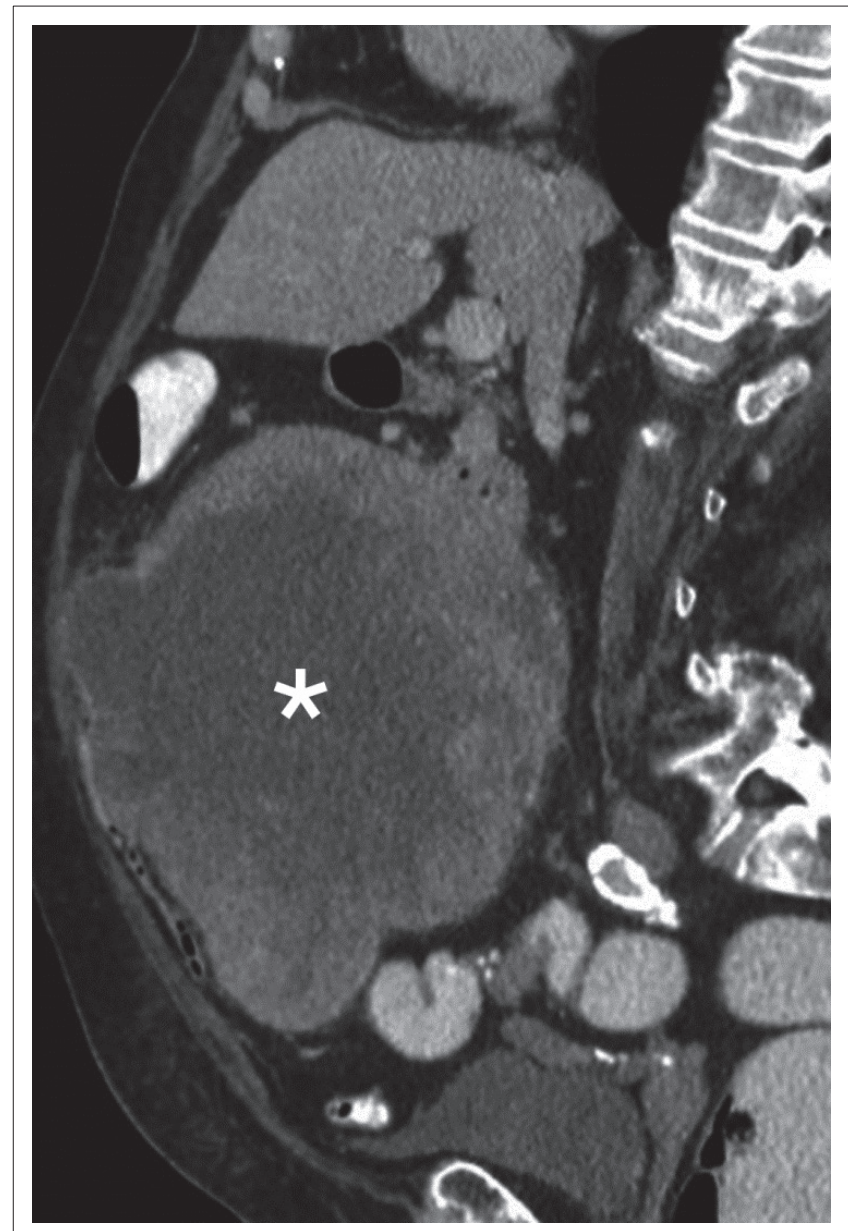

FIGURE 3: Sagittal computed tomography images of the mass (asterisk).

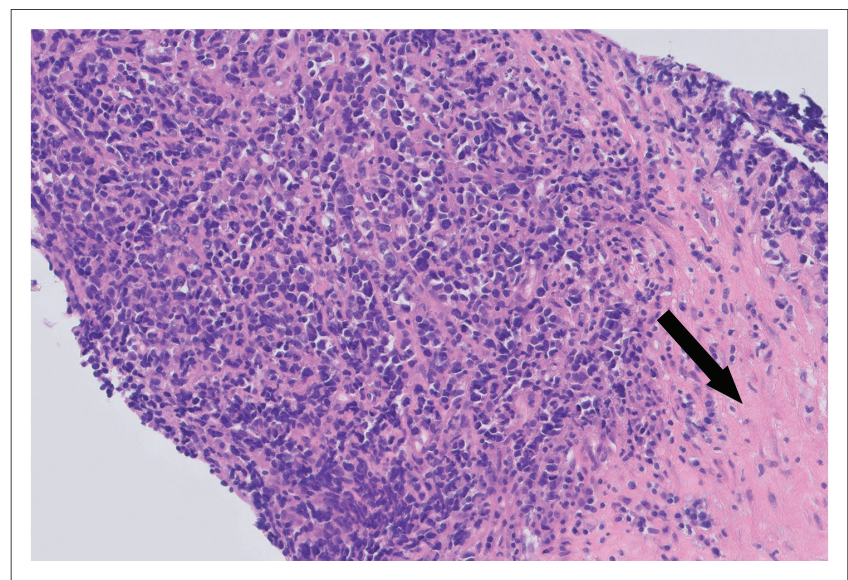

FIGURE 4: Histological image (Hematoxylin and eosin staining, enlargement 200x) showing compact growth of the high-grade small blue round cell tumour with focal desmoplasia (arrow).

- desmoid tumour (arising at the site of scarring from prior surgery)

- other soft tissue sarcomas (like synovial sarcoma and rhabdomyosarcoma). ${ }^{4,5}$

Extraskeletal Ewing's sarcomas in adults are large tumours that metastasise to the lung and can invade adjacent organs, although they tend to displace adjacent structures rather than invade them. They are aggressive tumours, 

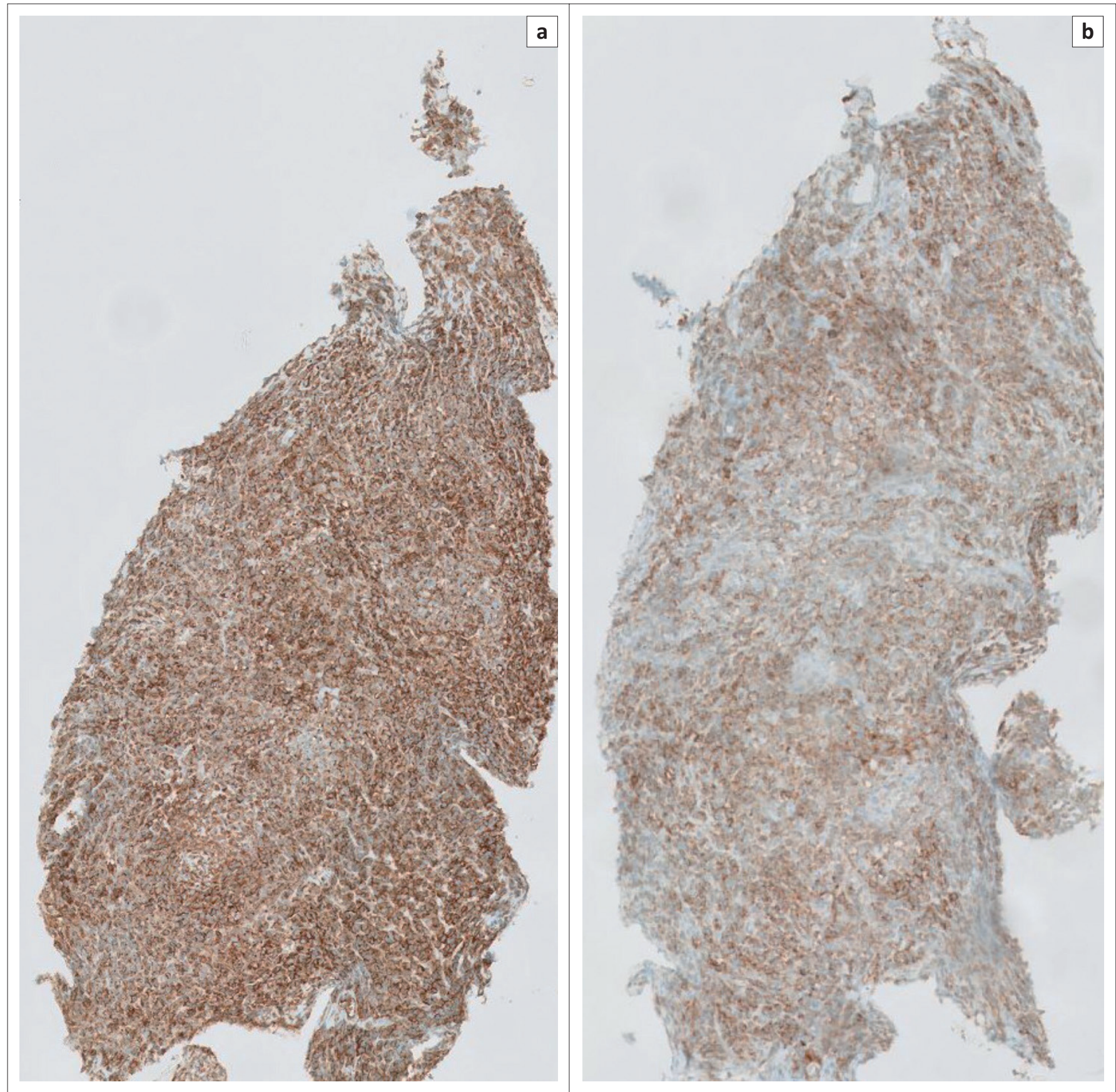

FIGURE 5: Immunohistochemical images (enlargement $10 \times 5$ ) showing positive CD99 and (a) synaptophysin (b) immunohistochemistry staining.

often with distant metastases and local recurrence and a 5-year survival rate of less than $50 \% .^{3}$

Patients with localised EES are treated aggressively with neoadjuvant chemotherapy, followed by surgery and in the event of inadequate surgical margins, postoperative radiotherapy. Molecular-targeted treatments are in development. ${ }^{2,3}$ The case discussed above was treated with neoadjuvant carboplatin-etoposide, followed by excision of the tumour and radiotherapy.

\section{Conclusion}

Extraskeletal Ewing's sarcomas are rare tumours and even more rare in the abdomen. They occur in an older age group compared to osseous Ewing's sarcoma, but are rare in the elderly. They should, however, be considered in the differential as this will help guide pathologists and clinicians in making the final diagnosis.

\section{Ethical considerations}

There were no ethical conflicts. This article does not contain any studies with human or animal subjects.

\section{Acknowledgements Competing interests}

The authors declare that they have no financial or personal relationships that may have inappropriately influenced them in writing this article. 


\section{Authors' contributions}

C.D.W. and K.C. performed the ultrasound and computed tomography scan on the patient. They followed up the histology results and the oncological treatment with I.V.d.B. and the oncological treatment with A.B., respectively.

\section{References}

1. Applebaum MA, Worch J, Matthay KK, et al. Clinical features and outcomes in patients with extraskeletal Ewing sarcoma. Cancer. 2011:117(13):3027-3032. https://doi.org/10.1002/cncr.25840
2. Javery $\mathrm{O}$, Krajewski $\mathrm{K}, \mathrm{O}$ 'Regan $\mathrm{K}$, et al. A to $\mathrm{Z}$ of extraskeletal Ewing sarcoma family of tumors in adults: Imaging features of primary disease, metastatic patterns, and treatmentresponses. AJRAmJ Roentgenol.2011;197:W1015-W1022. https://doi.org/10.2214/AJR.11.6667

3. Somarouthu $B S$, Shinagare $A B$, Rosenthal $M H$, et al. Multimodality imaging features, metastatic pattern and clinical outcome in adult extraskeletal Ewing sarcoma: Experience in 26 patients. Br J Radiol. 2014;87:20140123. https://doi. org/10.1259/bjr.20140123

4. Huh J, Kim KW, Park SJ, et al. Imaging features of primary tumors and metastatic patterns of the extraskeletal Ewing sarcoma family of tumors in adults: A 17-year experience at a single institution. Korean J Radiol. 2015;16(4):783-790. https:// doi.org/10.3348/kjr.2015.16.4.783

5. Ulusan S, Koc Z, Kayaselcuk F. Gastrointestinal stromal tumours: CT findings. Br J Radiol. 2008;81(968):618-623. https://doi.org/10.1259/bjr/90134736 